\title{
MEDAN PRESS: NATIONAL IDENTITY FINDING PROCESS
}

\author{
Wannofri Samri ${ }^{1}$
}

\begin{abstract}
Medan has grown really fast since the farm development in Deli, East Sumtara has begun in the end ! $9^{\text {th }}$ century. The development contributed a great impact to the development of the area sorounding East Sumtra. The cities surrounding the plantation had developed fast. Medan is one of the cities that develeloped as the impact of the wide development of the Ducth's colonial platation, followed by a great migration to that area from various nation. One of the most important development was Medan as a growing publishing center, bothfor bookand mass media, such as magazineand newspaper. Thepublishing figures came from various races, ethnics, and cultures, particularly from Aceh, Minangkabau, Java, Mandailing, and Batak. In addition, foreing publisher also existed, such as Europ, China, and India. Medan press development was good in the movements era, it considered as equal as Batavia, Surabaya, and Padang.
\end{abstract}

Key words: Medan Press, Almanak Sumatra, Indish Verslag, Deli Courant, De Ooskust, Sumatra Post, De Palnter, Pertja Timor, Sinondang Batak, Penjebar, Chinese Press, Mass Media, and Nationality Movement

\section{Introduction}

According to M. Said, during the colonial era, 46 newspapers and magazines were published in Medan. 35 publishing company was build by the native, 9 by the Chinese, 4 by the Dutch, and 1 by the Indian' descent (Usman Pelly, 1998: 164-165). Surely, the competition in that diversity is interesting in the context of finding the Indonesia'a identity, which was moving toward the unity in diversity. The competition among ethnics, races, and the publishing foundations was common. The condition had brought Medan to dialectic, become an improvement place for journalists. It is not a surprise that many Mendan's journalists had been popular since the movement's era and after. Iwa Kusuma Sumantri, BM Diah,

1Drs. Wannofri Samry, M. Hum, lecturer of the History Department of Universitas Andalas Padang. This Article has been reviewed by Prof. Said Hamid Hasan, M.A (Indonesia University of Education, Dr. Nana Supriatna, M.Ed (Indonesia University of Education, and Prof.Dr.Madya. Ahmad Abdul Razak (Universitas Kebangsaan Malaysia). For academic interest, the author can be contacted at email: wannofri@yahoo.com. 
Parada Harahap, Hamka, Zainal Abidin Ahmad, M Yunan Nasution, Soetan Makmoer, Rasuna Said, Adinegoro, HM Said, Ani Idrus, are some of many journalists during the movement era in Medan, who were popular in journalism world in their era and after. They were the popular journalists pioneering the Indonesia independence. The Islamic and national movement's figure M. Natsir and Soekarno had a polemic about Islam and nation in Pandji Islam (1930s). This polemic had been a reference for the study of Islam and nation in Indonesia. Soetan Makmur (Minangkabau) dan B.M Diah (Mandailing/ Sipirok), the press figures of Medan, were appointed the Minister of Information (Usman Pelly, 1998: 164-165)..

TheMedan'spress was veryimportant duringthemovementera, However, the study of Medan's press is very low, if not none. Eventhough the publishing press in Medan has been very importan since the beginning of the 20th century, but the academic study specialized in the mass media development in North Sumatra is hardly found. In fact, according to Usman Pelly (1998) and Said (1976), the press development in North Sumatra during the Indonesian movement era was very good. The Sejarah Kebangkitan Nasional Daerah Sumatera Utara, a history book officially published by the Government, does not even mention the history of the press development in Medan, unless in one paragraphy only (Depdikbud, 1977: 23). Some biography books and a few books had mentioned about the press development in Medan. The books mentioned about the press development in Medan were such as the book written by Arif Lubis (1958), Subagio I.N (1976, 1987, and 1989), Badruzzaman Busyairi (1985), Tridah Bangun (1990), Soekarno Mustofa (1978), Sahat P, Siburian (2009), 1987, M Said (1976), Dahlan (1976), and TWH (2001).

Another books mentioned about pers in Medan were the books written by Usman Pelly (1998), Basyaral Hamidy Harahap (1996), Mohammad Said, and HarryAPoeze(1989). Theinformation regardingthepresshistoryin Mendan could also be traced in Almanak Sumatra (1969: 974-975), this writting explored about the role and position of North Sumatra in the Indonesia Press development.

This paper studies about the press existence in Medan in the movement era or in 1902-1942. 1902 was the early year the native involved in press publishing in Medan, while $1942 \mathrm{~J}$ apanese entered J apan and banded the press publishing in Medan.

Press is the flexible term use for this paper, press is any and all activities related to publishing, while in this paper press may only refers to the publishing of newspaper, magazine and various activities related to those. The terms 'movement' and 'development' are used in this paper in parallel, the proses of modernisation. The important question of this paper is: how is the form of press publishing in the movement era in Medan? What is the role of press publishing in Medan, in the process of finding the Indonesian identity? 
HISTORIA:

International J ournal of History Education, Vol. XII, No. 1(J une 2011)

\section{Medan in the Movement Era}

Medan is a city in the Nothern Sumatra. This city the development of this city was fast since the plantaion area was opened in the East Sumatra in the end of the $19^{\text {th }}$ century. The plantation had attracted many domestic workers and foreign workers. Medan as a city that was developed by the colonial plantation had been grown in a multi ethnic condition. In 1930, Medan had gown as an important city in Sumatra. In 1930 Medan population had reached 76.584, it was the second biggest city after Palembang, which at that year its population was 108. 145 people. Medan population was more than Padang, which population was 52.054 people. Whereas, until the second decade of the 20th century, Medan was smaller that Padang, West Sumatra.

The plantation development in the East Sumatra had affected Medan's development. Medan had grown fastinto amulti ethnicand racecity. Thecomunity of European, Chinese, Arabic, and Indian grew in Medan. The immigrant from J ava, Minagkabau, Aceh, Mandailing, Sunda, Melayu-Deli, and Batak were also made Medan more crowded. Batak-Mandailing, Melayu and Minangkabau were the ethnics of Sumatra that involved in the press movement and publishing in Sumatra. Every ethnic has their own background and interest in the press publishing.

A strong competition, the colonial dynamic, impeliralism has pushed every race, ethnic, and comunity to reflect on their own identity. Press Publishing was chosen by every ethnic or community as the means of information and comunication. Press spread the news about their community existence and problems, which later improved to form the nation's identity. The matters of multi-ethnic and the development of various social problems had also affected the movement spirit in this city.

The original ethnicslived in Medan are Batak (Karo, Angkola, and Mandailing) and Melayu. Since the end of the $19^{\text {th }}$ century the people of Minangkabau, J ava, Banjar, Sunda, Cine, Arab, and India or Keling had collectively entered Medan. From the North came the people of Aceh.

One effect of the plantation capitalism development (onderneming) in Deli was the development of Medan which had become a compelx city: crowded, multi-ethnic, and the central of the social- politic movement in the Western Part of Indonesia. The Medan great and exotic development had made the European call it Parijs van Sumatra and De meeste Europ in Indische-stad.

Eventhough many peoplefrom multi-ethnic had lived in Medan, Penjedar (31 J uli 1941) explained the social movement development in Medan by mentioning only three important native ethnics in Medan, which are Tapanuli, Minangkabau, and Java. These three groups had different characteristic. Tapanuli and Mandailing people were conservative or orthodox. They were very fanatic with the convensional doctrine, did not like to improvise in the matter of religion, and not talkactive. Tapanuli people were considered to be cold-blooded, introvete, patient, not interested in new matters, therefore their improvement was slow. There were two Tapanulis, the South and the Central. The Central Tapanuli 
was considered more aggressive, more radical, and tend to like changes, that's why most of them left the orthodox doctrin and adapted to the improvement. Meanwhile, the people of Minangkabau were considered as a more dynamic ethnic, they like development and modern matters. The J avanese, because they who came to Medan were the plantaion workers, they tend to just follow. Many J avanese were suffer in Medan and forced to be "Nyai" (mistress) (Penjedar no 31, 31 Juli 1941.)

According to Anthony Reid, the spontaneous migration of Indonesian to the prosperous East Sumatra contributed an important effect to the social life, compared to the bigger number of contract coolie. Generally, those migrants were coming to the developing cities. Eventhough they were not as much as the Chinese, their arrival had supported the development of that region. The profesion of those migrants were office clerk, teacher, handyman, salesman, foodshop keeper, and manyother professions in service area. Their migration was definitely had support the development of Medan as the residential capital city of East Sumatra (Reid, 1979: 58).

The population of East Sumatra in 1930 was 1.455 .051 people. This was significant compared to the year of 1920 which was 1.042 .930 people, and 1905 which was 450.941 people. The Tapanulis population in 1905 was 410.939 people, in 1920 increased to 850.961 people, and in 1930 became 1.034.108 people (Indish Verslag, 1930).

This fast growing population had a significant effect, particularly poverty as, the result of competition and economy disparity. Medan, as the main city, indicated that effect. The poverty in Medan resulted in the particular problems, most of them did not have houseand job. Many beggars (bedelaars) wereroaming on the main streets, bus stops, stations, and inside the markets. The Press of Medan grew in that kind of situation, in the situation of plantation capitalism development and the growing of new awareness among the natives.

\section{The Development of Press Publishing in Medan and the Sorrounding}

The first newspaper published in Medan was Deli Courant (1885). Deli Courant was written in Dutch and the purpose of this newspaper was as a mean of communication between the colonial plantation company and the community of the plantation, and also the natives in general. According to the editor (Waarnemend Readcteur) of Deli Courant, J acques Deen, the publishing of that newspaper was to eliminating the dependence of news paper from Semenanjung Melayu. The benefit was that the colonial community and The Dutch's Colonial Government in J ava would be able to get information about the East Sumatra directly from the newspaper published in East Sumatra,The printing of this newspaper was simple, by using a steam machine (stoomdrukkerij). The initial total printing was 150 sheets. It was provided for more or less 688 European in the East Sumatra Residence (Ooskust van Sumatra). The important role of Deli Courant had improved the company into Naamlooze Vennootschap. Most 
of the capital to build Deli Courant'came from N.V Deli Maatschappij, the biggest plantation company in the East Sumatra. In any way, this newspaper was expressing the investor's interest. Before Deli Courant (18 March 1885) publishing, the people of East Sumatra was reading newspaper published in Singapore and Semenanjung Melayu which included; Pinang Gazette, Singapore Free Press and Singapore Daily. This publishing was delivered to Belawan Medan by boat that was arrived twice a week. The publishing of Deli Courant was followed by another European newspaper such as, yaitu De Ooskust (1895), Sumatra Post (1899), and De Palnter (1909)

Many Malayan newspaper was published after the publishing of Soerat Kabar Berbahasa Melaijoe (1856). The publishing of newspaper in Malayan language in Medan was pioneered by Pertja Timor (1902-1912), it was issued twice a week in the subscribe price of f. 1.50 and retail price of f. 0, 75 cent. Pertja Timor was published by Drukkerij J. Hallerman and later the name was change into Varekamp. Pertja Timor was the first Medan's newspaper whose editor is also Indonesian. The editor was Chatib Radja Soetan, the first journalist in Medan. Later, he was replaced by Mangaradja Salembuwe. Salembuwe came from Angkola J ae, $10 \mathrm{~km}$ from Padang Sidempuan. He graduated from Kweek School of Padang Sidempuan. He was known as a critical person. Eventhough he worked in a Dutch newspaper but he was often critize the policies of Dutch's Governement. In 1912 Salambuwe was replaced by Moesa, which at the same year got a sentence (pers delict) from the court (Said, 1976: 8-9)..

The Pertcja Timor publishing and the involvement of Chatib Radja Soetan, Salembuwe, and Moesa in the publishing had marked the beginning of the native journalist activities in Medan. Eventhough Pertja Timor was not in particular expressing the native's interest but it was written in Indonesian, and little by little critize the power in that state (Said, 1978: 8-9 and Lubis, 1958: 223)

After Pertja Timor, many newspapers written in Malayan was starting to appeare. In 1910 Pewarta Deli was published in Medan, the news paper that was pioneered by the Batak and Mandailing union. This company had become really famous before the J apanese era. Another newspaper written in Malayan was Andalas (1913), Perempoean Bergerak (1919-1920), Sama Rata (1919), Benih Merdeka (1922), and others. Newspaper written in Batak language was also published, such as Narumonda (1903), Sinondang Batak (1904).

The population of the Nederlanche-Indie in 1920s was about 50 million people, 170.000 were including the European and Foreign East. The number of mass media in Dutch was almost as many as the mass media in Indonesia, 32 compared to 39, respectively. This was because many Indonesian speak Dutch. The circulation of the Dutch newspaper is bigger that Indonesian newspaper. The newspaper in Dutch could reach 6000 to 9000 exemplar, while the newspaper or magazine published by the native was less than 1000-6000 exemplares (Prakoso, 1984). There were even the native newspaper that only publish 100 exemplares, which in Pewarta Deli was called as the news paper with the motto of leven en laten leven (are also foraging)( Pewarta Deli, 27 December 1937). 
Infact, after 1920s the press publishing activities were good enough. These publishing activities were associated to the more litterate natives, they were not only able to read the Rumi and J awi letters, but also understand Dutch. In 1930 there were more or less 700.000 who can read in Sumatra and more that 27.000 people were able to write (Indisch Verslag, 1940: 126). This condition had supported the press development. Many people had finally realized that every person may discuss, argue, and critize every matters they knew. However, the illiteracy development was not always followed by the press production development. People loved to read but many of the subscriber and agent did not send their subscription fee to the publisher (Pewarta Deli, 3 March 1936).

This problem was not only occured to Perwarta Deli but also almost all of the press publishers had complained about this unpaid subscription fee. In fact, in that era the financial source of the press was the subscription fee, not the adverstising.

Several magazines were also published in Medan, such as Abad XX (Chief editor by Adi Negoro and Mochtar Nasution), Pedoman Masjarakat (Hamka), Pandji Islam (Z. Ahmad), Dewan Islam (M. Arsjad and TH Lubis), Soeloeh Islam (Kiai MA Madjid Abdullah), Penjebar (M Said and Abdul Xarim MS), Sinar (H. Bakri Sulaiman), Deliana (Zahari), and Pertja Timor (D. I. Lubis). They were also published romance such as Roman Pergaoelan, Tjendrawasih, Alhambra, etc (SPS, 1958: 239). Before the World War II, the mass media in Indonesia had attracted the elites because they were reporting actual news that might open many people awareness. He realized that mass media is really important. The awareness of the press effect had forced the press to provide a beter image. This image affected their income. Therefore, presses created image in various ways, they were often use tricks (trukje). Variety of trukje were made. There were editor that made false subscriber's letters and published the reader's letters. The editor might wrote, "we have recieved tens letters". Another way was by insulting another mass media.

Publishers were also marked up their newspaper circulation number to provide image for their customer and advertiser. According to an article in Abad 20 magazine, many mass media had tricked their readers and advertiser. Many newspapers said that their circulation reached 4000 exemplar, however, if the published merely use the manual little printing machine, that statement was doubtful. If they printed by using small printing machine (which at that era was moved by dynamo), in an hour they could only produce 1 page. In that era, the press wer mostly had 4 pages. With that capacity, they had to print 4 pages in 4 hours, which means they need 16 hour to print that many newspapers. They also needed more time to arrange the letters, arrange the printed result, the whole process needed almost 21 hours. Therefore, the truth was the newspaper printed with a small mechine should only able to be produced around 500 exemplares per issue. 
HISTORIA:

International J ournal of History Education, Vol. XII, No. 1 (J une 2011)

\section{The Chinese Press}

TheChineseinvolvementin printingand mass mediain Indonesia, particularly in Sumatra, has been since the end of the $19^{\text {th }}$ century. The initial purpose of the publishing was to support the Chinese nationalism in China. Until the movement era the connection between the immigrant Chinese overseas and the Chinese in the China land itself. However, the orientation of all Chinese could not be equalized. They were defined into 3 categories. The first was the Pure Chines (Cina totok/singkehs). They were the Chinese that was directly arrived from China, most of them were admitted themselves as Chinese. Most of them were coming to the Dutch Nederlansche-Indies as merchants, some of them come to work. Their minority was from the higher social class. The orientation of most of them was to obtain a better finance. Second, the Peranakan Chinese, they were the descent of the Chinese, they were born and grown up in this Dutch East Indies. The Peranakan Chinese was the urban community, they lived in the port area and become the merchant or service seller. Most of Peranakan Chinese were able to speak Malayan. Third, The Chinese who wanted to be the citizen of Ducth East Indies, they were politically have a position in the Dutch Colonial Government (Williams, 1960: 10-11). This classification are not strict because there were Chinese who came directly from china and socialized with the natives, such as Tjong A Fie in Medan. TjongA Fie was one of the biggest business men in Sumatra who dominate the East Sumatra. His business was in field of plantation and fishery. Hewas one of the investor of NV Sjarikat Tapanoeli, the most famous printing company in the movement era. He had also been the Captain of China in Medan

The Chinese Nationalism was initially involved in the Pan Chinesism that was in form of Chinese association such as Tiong Hoa Hwe Koan (THHK). This spirit was also followed by the Peranakan Chinese by publishing a newspaper in Malayan. Therefore, both the Chinese descent Asociation and the Chinese newspaper in Malayan was the product of Chinese nationalism. The Chinese Nationalism Movement was increased since the first decade of the -20 century (Suryadinata, 1976: 11). The form of Chinese movement in Sumatra was also seen by the appearance of the several Chinese Association and the newspaper in Malayan. One of the good Chinese company was the N. V. Sumatracche Handelsdrukkerij, which issued the newspaper such as Andalas, Pelita Andalas, The Sumatra Times, and The Sumatra Bin Poh. The first leadr of NV Handels Drukkerij was Oeng Beng Seng and Thio Gim Tong.

Andalas (1912-1924) was the first biggest Chinese newspaper written in Malayan in Medan, and East Sumatra for general. It was published for the first time on 1 February 1912, when the Indonesia movements were everywhere. The administration and editorial office of Andalas was at Spoorstrat 10, phone number: 334. This newspaper was published 3 times a week in the size of 54,5 $\mathrm{cm}$ x $39 \mathrm{~cm}$. Every newspapaer ussualy consisted of eight pages. When it was issued for the first time, Andalas was lead by Thio Gim Tong. The editor chif (Hoofdredacteur) was Tan Thwan Khang and administrator was Lan Boen Kiat. 
The responsible editor (verantwordelijk redacteur) was Radimin, the editor assistant (mede redacteur). In 1923, Andalas leader was Ong Beng Seng and the Administrator leader was Tan Eng Chong. The price for each exemplar was f 0.15 and for subscriber in the Dutch East Indies was f 2.05 for three months, outside Dutch East Indies was $\mathrm{f}$ 3.oo. The advertising fee per word was 5 cent, for 1 issue was f. 1,-. In 1923 the price was increased int to f 3.30 per three months for the Duthc East Indies area and f. 5.30 outside the Dutch East Indies are.

SomeIndonesian journalist that had worked asjournalistand editor in Andalas newspaper was Muhammad Samin, and Syarikat Islam activist and the lawyer of Mr. De Heer. There were also Toedjoeng Mohamad Arif, Mohamad J oenoes Is, and Abdoerrahman (Said, 1976: 14).

Most Andalas reader did not want to pay thesubscribing fee. This was common experienced by most newspaper in the Dutch East Indies. According to Andalas, they were often colletcting the subscribing fee, but they were ignored, while the production fee for producing the newspaper was high. Advertisement feecould not cover the deficit occured to this mass media. Eventhough Andalas had announced it several times in every issue but the subscribed ignored it. Below is the quote of Andalas anger and disappointment:

"Diantara abones "Andalas" ada beberapa orang yang kendatipoen soedah berkali- kali dikasih ingat dan ditagih tapi masih alpa loenaskan ia poenja toenggakan oetang oewang abonement "Andalas, Advertentie dan drukkerij, orang jang demikian kita anggap ada terlaloe dari misti maka padanja poen kita djadi merasa ada mempoenjai kewadjiban boeat berlakoesebagaimana mestinja. Ini ada pemberian taoe jang penghabisan kali boeat peringatan pada orang jang masih ada sangkoetan oeang abonement "Andalas", advertentie dan drukwerk. Dan lekas diselesaikan oetangnja, mereka jang tiada perhatikan ini pemberian tahoe djangan djadi menjesal dan mengoepat dan bersama dengan itoe akan diserahkan oetangnja pada advocaat dan bersama dengan itoe akan disiarkan djoega namanja di soerat kabar Andalas"

"Among the "Andalas" subscriber there are somebody who's has been warned several time and billed but he kept ignoring his arrears fee of "Andalas, Advertentie dan drukkerij". We considered that person's attitude as improper, and therefore we the right to do the proper act. This is the last warning for those who still owe us the "Andalas" subscribing fee, advetentie and drukwerk. Any debt shall be settled immediately. Anyone ingroning this warning shall not regret that we will submit the debt list advocat and announce the names in Andalas newspaper.( Andalas, 29J anuary 1924).

Pelita Andalas (1924-1941) was published by N.V. Sumatra Handels Durkkerij, a Chinese publishing company. This newspaper was the replacement of the bankrupt Andalas. The motto of this newspapaer was "orgaan boeat segala bangsa", it means the newspaper was marketed to and read by all communities. 
The size of this news paper was $55 \mathrm{~cm}$ x $37.5 \mathrm{~cm}$, this news paper was published in 8 pages, and sometimes 10 pages.

Pelita Andalas published three times a week, on Tuesday, Wednesday, and Saturday. This news paper was led by Jap Jean Tjian, a rich and popular merchant in East Sumatra. He was also a commissioner of NV Sumatra Handels Drukkerij, which published Andalas and Sumatra Daily News (written in Chinese). Because he would loved to develop the East Sumatra, Jap bought the bankrupt NV Sumatra Handels Drukkerij. He bought the company including the financial problems. This newspaper was Jap effort with the support of his Chinese colegue to provide a facility for the Chinese and Native communities (Pelita Andalas, 23 September 1924). In the first issue of Pelita Andalas we can read Andalas purpose to enlighten the entire Sumatra, not only for Chinese but also for the entire people of Sumatra. The purpose for this newspaper was to maintain justice, to critize fairly, and as awareness facilitation for the whole nation.

\section{The Native's Publishing}

The native's had been involved in publishing since the end of the $19^{\text {th }}$ century, however, the native's company appears in the first decade of the 20th century. Many considered that the first native press was Medan Prijaji (1907). However, in Sumatra, Dja ENdar Moeda had started to publish Tapian Na Oei in 1900 in Padang. However, Tapian Na Oeli was not a big company, it was mostly supported by his passion. He was a journalist that started his carrier as a teacher and an asistant reported in Padang. This newspaper had two categories, the religious and the nationalist. But both newspapers have no strict boundaries. In fact, the religious newspaper will finally pump up the nationalism spirit in Indonesia. This was closely associated to their Indonesian native readers. Under the suppression of colonialism and imperialism, the native awareness of their own identity is a must.

The Christian mass media in North Sumatra has been existing since the end of the 19th century, it was Surat Keliling Immanuel that was pioneered by a missionaries named J acobus Henricus Meerwaldt (1890). Surat Keliling Immanuel had changed into Surat Pasaoran Immanual of Huria Kristen Batak Protestan (HKBP), a magazine for comunication and Christian spreading in Batak. Immanuel Magazine was managed by the Batak people since 1930, prior to that it was managed by a bible organization, Rheinische Mission Gesellschaft (RMG)(Siburian, 2009).

The Islamic press existence in Indonesia could be traced since the beginning of the twentieth century. The Islamic press publishing could be viewed in two orientation. First, it was published to strengthen the Islamic faith, it could be seen in the articles expalining about islamic matters, from faith, fiqh and another matterd related to the Moslem. The second was the Islamic press tah support the Islam and political movement that was considered could disturb the existence of Islam. Particularly during the national movement era, the Islamic mass media had maintain the growing of Indonesia nationalism and opposed the colonial. 
During the Indonesia movement era, particularly after the third decade, the Islamic media publishing was quite a lot. The publishing was particularly grew in Padang, Medang, Batavia, and Bandung. The north Sumatra was one of the importand places in Islamic press publishing in Indonesia.

During the Indonesia movement era, there were 20 Islamic press were published in North Sumatra, both newspaper and magazine. The Islamic press in North Sumatra was published in Medan, Sibolga, Pematang Siantar, Tanjung Balai, Tarutung, and Pangkalan Berandan.

The main city of the Islamic press publishing in the North Sumatra was Medan, the capital city of the East Sumatra (Oostkust van Sumatra). Some magazine published was including Soeloeh Islam, Medan Islam, Al Hidayah, Dewan Islam, Seroean Kita, Menara Poetri, Sinar, Tafsir Al-Qur’anul Karim, Pedoman Masjarakat (1935-1942) and Pandji Islam (1934-1942).

The Islamic publishing from the North Sumatra was distributed to various places, domestically or internationally, such as to the cities of J ava, Kalimantan, Singapore, and Malay Penisular. Altough it was widely distributed but most Islamic press does not exist for a long period. It was because the financial problem and the poor management. The advertising in Islamic press was less than maganize or another newspaper. Many reader were also did not want to pay or sending their subscribing fee the the published.

The Panjdi Islam and Pedoman Masjarakat magazines which were published in the middle of 1930s were the very important magazines. Both were popular at that era. The Islamic press had been active in enlighting the nation's knowledge by their content of various knowledge in the, both from the Islamic world or outside the Islamic world. It had been the media of social, culture, politic, and economy information. They were the means of communication and grew the spirit of the same boat that will force to create the nation's identity.

Pandji Islam and Pedoman Masjarakat were two publishing managed by the strict Moslem figures. Both magazines were survive longer than the others. Both had become the medium of national polemic and Islamic for Indonesia's important figures such as Soekarno, M. Natsir, Mohammad Hatta, and Hamka.

The Islamic press had an important role in the Indonesia history process. They were the activator of national dialectic and Islam. It was possible because the opportunity to have polemic is widely open in press, such as the polemic between Pedoman Masjarakat (Medan) and Al Lisaan (Medan) and between M. Natsir and Soekarno in Pandji Islam. Let us discuss the polemic between Soekarno and M. Natsir and the polemic between Al Lisan and Pedoman Masyarakat.

Pandji Islam (1934-1942) was published for the first time in 1934 with motto: "minggoean wetenschap Islam popoeler" lead by Z.A. Ahmad, editor was A.R. Hadjat, the "Barisan Poetri" was managed by Rohana Djamil and Administrator was M. J oesoef Ahmad. Another editor from Pandji Islam was Sjamsoedi Z. and administrator was Qasim Ahmad and the Islamic literature was managed by M. Siddiq Soein. The office was at Louisestraat 59, Medan. This magazine often invited famous writes such as M. Natsir who was a famous Islamic figure in the movement era until the Indonesia independence era. The 
Polemic between M. Natsir and Soekarno about Islam had made the magazine really popular and remembered in the Indonesia history.

Pandji Islam had announced that it was the Islamic magazine. However, the content shows that the magazine was strong in Islamic ideology and nationality. As the famous magazine before the Japanese occupation, Panjdi Islam was often made big events, including their aniversary party on 15-16 J uly 1939. On their anniversary, which were uncommon in that era, they invited many figures, writters, and readers. This event was very special because it was attended by A Supremely Honor Tengku Othman, the crowned prince of Deli, the Chinese consultant in Medan, Mr. Che Tit Fan. This event was also invited several press editors form Sumatra and J ava. They also had a meeting between Panjdi Islam and reader (Pandji Islam, 31 J uli 1939). Pandji Islam extravagant anniversary party was also to rise up the prestige of native press.

Pandji Islam progress was very important for the press development in Medan, and had become pride for Moslems. Pandji Islam publishing was not only proud Moslems but also respected by the Christians. On 5 May 1939, a Christian magazine, Pertandaan Zaman, sent a letter to Pandji Islam's editor, which says:

“ Toean-toean jang terhormat: apabila kami menerima Pandji Islam dari sewaktoe kepada waktoe jang lain, maka terlihatlah oleh kami toean2 poenja oesaha jang moelia di dalam mengemoekakan angan2 jang dirasa oleh toean2 itoe benar. Dari sedjak terbitnja Pandji Islam selaloe kami koempoel nomor2 itoe mendjadi djilid2 jang bagoes, jang dalamnja kami dapati banjan isinja jang indah oentoek wetwnschap. Tentang Pebedaan faham itoe soedah ghalib, kita tidak selamanja sedjalan. Tetapi tentang pendirian, dan setjara nmanoesia,m kita semoea saoedara adanja, kami menghormatkann satoe sama lain, seperti kamim lihat dalam Pandji Islam, dan begitoelah adanja toedjoeann kami, Meskipoen P. Zaman tjoema $1 \mathrm{x}$ seboelan, sedang Pandji Islam 4 of $5 \mathrm{x}$, tetapi toean2 tidak pandang roehi apabila mengoendjoengi kami. Kasilah di sini kami menjatakan kami poenja penghargaan pada Pandji Islam jang soedah lama kami kandoeng tetapi baroe sekarang kami oetarakan”.

Tabik dan hormat kami, atas nama Redactie dan Administratie.

"Dear sirs: We have observed Pandji Islam from time to time, and we can see that you have a noble attempt to express the ideas you considered as right. We have collected all issues of Pandji Islam and bundled it, and we have realized that it has many beautiful content to expand our knowledge. Different opinion is common; we cannot always be in the same path. But as human, we all brothers, we respect each other, as we seen in Panjdi Islam, and so we are. Although P. Zaman is issued once a month, while Pandju Islam is four or five 
time a month, but you respect us. We are expressing our appretiation that we have had for a long time and had the chance to express it this moment".

Sincerely yours,

On behalf Editors and Administration (Pandji Islam, 31Juli 1939)

This letter also explicitly shows that Pandji Islam was not an exclusive magazine, it could be also accepted by the people who had a different faith of religion.

Pandji Islam contained news and written materials associated to the nationalism movement process and Islam in general Every issue of Pandji Islam always contained news associated to Indonesia and Malay Penisular, it also contain writings of the movement figures such as Natsir, M. Hatta, Soekarno, etc. Pandji Islam also contained literature works, information regarding the islaminc world development, and the slamic knowledge. The first page was always started by the editor writing that ussulay about the problems occurred in Indonesia.

The editor's writing could be about anything; the Dutchs East Indies' politic, Doenia Islam, Islamic religious problem, etc. However, the editor's writting tittle was usualy about the hot issues. Such as when volkraads started their new period in J une 1939, the tittle of the editorial wrritng was "Mengetok Kawat Sewaktoe Volksraad Moela Diboeka" (Pandji Islam, 19 J uni 1939). Another important magazine was Pedoman Masjarakat (1935-1942). The magazine was established in 1935 upon the inisiative of the moslem journalists in Medan. It was published every Wednesday by Asj-Sjoera Medan and printed in N.V Sumatra Hadeld Drukkerij Medan. In 1935 this magazine was lead by H. Asbiran J a'Coub. In the early year the chief editor was $\mathrm{H}$. Bustami Ibrahim and the general affair was managed by M. Rasami. The foreign assistant was S. J aafar (India) and A. Loathfia (Siam). Pedoam Masjarakat representatibe in Batavia Central was Td. Mhd. Alhabsi. This magazine's principle was Islam, it could be seen in its motto attached, "Memadjoekan pengetahoean dan peradaban, berdasar Islam ( To advance Knoeledge and civilization Islam)."

Initially Pedoman Masjarakat was smaller and the format was simple, $19 \mathrm{~cm} \times 24,5 \mathrm{~cm}$ with 24 pages. Initially this magazine was published by ElBoesra Medan, with the cover headline letters was green. In 1939 the magazine was published in of $28 \mathrm{~cm}$ x $21 \mathrm{~cm}$ during the era of Haji Abdul Malik Karom Amarulla(Hamka), a fampus writes in theIndonesiamovement era (Rosidi, 1990: 195). Hamkan could become the Chief Editor (Hoofd Redacteur) in Pedoman Masjarakatbecausehewasrecomended by M. Yunan Nasution, an editorassistant in Pedoman Masjarakat, whose also a Moslem young intellectual activities in Medan (Busyairi, 1985: 97). Hamka had madea change in appearanceand content of Pedoman Masjarakat. Thearticle was morevarious, thereare "Editorial Notes" at the front page, "general knowledge", "Nature Science", "History", "Women's world", "Islamic world", "general chronicle", "life's reflection", "Poems", "Sacred Corner" and "News". Hamka was often write for the "Life Reflection" column. Hamka romance was the important feature in Pedoman Masjarakat. Hamka's 
works in Pedoman Masjarakat was madeinto a book and had becomethepeople's favourite. The book was including Tenggelamnya Kapal Van Derwijk, Di Bawah Lindungan Kabah, Merantau ke Deli, Tassawuf Modern, 1001 Soal-soal Hidup, Filsafat Hidup, Lembaga Budi, Tuntunan Jiwa. Another works that had made into a book was Harga Peradaban Barat (Dr. M. Amir), Penuntun Pergaulan (M. Yunan Nasution) (Busyairi, 1985: 98).

Pedoman Masjarakat had pledged to advance the ideologi of Islam, Hamka as the editor after 1935 was continuing the existing foundation. Hamka added new color on the existed foundation and firming the magazine's foundation. Hamka contribution to the magazine related to the literature contain of that magazine, and a wider chance for the Islamic ideas in Indonesia. Hamka was also use Pedoman Masjarakat as a medium to spread the literature works which later made into books.

Hamka influence could not only be seen in the content structure, but also the impression to the reders. Pedoman Masjarakat had become a popular and leading modern Islamic magazine. This progress was also because of Hamka's policy to invite famous writes from various community such as M. Natsir, A. Hasan Bandung, H. Agis Salim, etc. He was also wider the distribution to J ava, Kalimantan, Sulawesi, Singapore, and Semenanjung Malaya, which made the circulationincreasedfrom 500 to 4000 beforeJ apanesearrived in Indonesia(Rosidi, 1990: 195-196). This distribution was really good for the native's magazine.

Hamka joint Pedoman Masjarakat in the early 1936 and he had firming the magazine's identity as the Moslem mass media. In the $20 \mathrm{~J}$ anuary 1939 issue, in his early writting on that magazine, he wrote "Islam is above all, it is the actual Allah's religion. I move in Islam, In the name of Islam I lead this magazine. From the beginning to end. Insyaallah!" Hamka explain that he would continue the publishing of Pedoman Masjarakat in Islam to make it stronger. In that magazine he would contained about the Islamic art, Islamic civilization, Islamic culture and chronicle of great people. Pedoman Masjarakat tried to be the "page of morals" and various Islamic knowledge. Hamka influence in this magazine was the more Islamic contains and his works that was really famous until Malay Penisular. Hamka was not confined himself from political problems according to development of the Indonesian movement.

\section{Nationality in Medan's Press}

Press was the important part in the nationality development. By press, an ethnical group and race would know each aother, therefore they would try to identified themselves in social, culture, economy, and politic. The term of Indonesia that was strengthened in the third decade of the $20^{\text {th }}$ century was because the strengthened of the press role.

According to Ernest Renan, there are two matter of a nation development: first, every society share the same history; second, the society should have a desire to live together as a nation. Renan said that without people, language, religion, 
a collective need, and area, there would be no nation. Karl Kautsky stated taht a nation is a unity of an attitude from a historical experience. Karl Radek was also said that a nation is believe, the society awareness to unify them in a group, a nation (Soekarno, 1970: 38-39). The beliefs of the Indonesia movements figures could be read in Douwes Dekker ideas, that what form a nation was not a unity of race, ethnic, religion, and geographic, but the unity experience and unique solidarity in the people of Indonesia (Elson, 2009: 22-23).

According to $\mathrm{B}$. Anderson, publishing, including press is very important in developing the nationalism of a nation. A printed language would give a foundation of information exchange to develop a collective awareness. It would develop nationality from the language that would be different from their mother language (Anderson: 61-64).

According to the explanation in various newspapers, the name of Indonesia was not popular among the people of Indonesia, at least before 1940. Before that year, eventhough the name was often written in the mass media, but it wasn't common for the common people. There were an assumption that the common people were shy or feeling odd using the word Indonesia. Previously, to refer to their identity they use their ethnical identity, such as "Aceh people, Batak people, Minangkabau people, J avanese, Sundanese, Bugis, etc. In addition, the Colonial Government ussualy used inlander, inlandsch, and Nederlander Indie to refer to Indonesia. Some people called the native people with inhemsch.

“ Satoe taktiek jang loetjoedjoega dari orang2 jang tak berani menjeboet Indonesia itoe, ialah pertakataan inhemsche sebagai pengganti indlansch karena taksoeka menjeboetindonesisch. Tapi kalau orang iitoemengetahoei , seboetaninhemschitoe sebetoelnja kosong , tak berarti apa2. Siapa sadja bisa menamakn dirinja inhemsch. Orang Belanda oempamanja adalah inhemsch dari negeri Belanda, orang Inggris idem dari tanah Inggris, orang Djerman dari negeri Djerman dll. Tapi oleh karena inheemsche itoe boekan nama, dan orang itoe perloe diseboet nama bangsanj, maka haroes diberi nama jang betoel2 nama dan tidak setengah2 nama

"A funny trick from people who do not brave enough to say Indonesia is the word inhemsche to replace indlansch because they don't like to say indonesisch. If only they know that inhemsch means nothing. Anybody could say that he is inhemsch. For example, the Dutch is the inhemsch from Netherland, the English is also the inhemsch of England, the German from German, etc. Because inheemsche is not a name, and they need to mention the nation's name, it should be the real name, not a just a regular name (Penjedar No 29, 16 J uly 1939).

In this confusion about the Indonesia name, an Indonesia political figure, Soetardjo, had propose a petition to the volksraad that for every official letters the name of Indonesia shall be used to refer to Indonesia, as well as the red and white flag was approved as the national flag of Indonesia.Soetardjo proposal was 
ignored by the government because it would complicate the state structure. But the government did not provide a concrete reason.

Below is a joke about the name of Indonesia:

"Perkara nama itoe ada soeatoe leloetjon dari pengalaman Lasiak Poekor sendiri. Waktoe dia ada perkara di Djawa, dia ditanya bangsa apa. L. P. mendjawab bahwa dia bangsa Indonesia, lantas dapat djawaban bahwa itoe boekan nama bangsa. Laloe ditanja lagi, apa bangsa Djawa atau tidak. Lantas ditanja, datang dari mana, jang didjawab LP, dari Tapanoeli. Pegawai itoe entah keloeaan sekolah apa, tapi dia bilang tidak tahoe, dimana Tapanoeli. L. P. kemoedian bilang, dari Soematra. Mendengar itoe dia laloe toelis bangsa Soematra, baroe kali itu LP dengar bahwa bangsa Soematra ada."

there is a joke from the experience of Lasiak Poekor himself. When he was in J ava, he was asked what was his nationality. L. P. answered that he was Indonesian, then he was told that it was not a nation. Then, he was aked once again, wheter he was J avanese or not. The next question was where are you from, LP answered from Tapanuli. It was not clear where was the officer graduated from, but he said that he don't know where Tapanuli is. Then, L. P. Said, from Sumatra. Hearing that the officer wrote the Sumatra nation, this was the first time LP heard that the nation of Sumatra has ever exist." (Penjedar No 29, 16 J uly 1939).

This joke shows several matters. First, the understanding about the name of Indonesia had not yet known by all people, both the Indonesian and the colonial officer. The Indonesian had not understood the countries of Indonesia. This was proofed by the fact that a controleur in Padang Sidempuan (North Sumatra) did not know Indonesia when he shoul know because the name of Indonesia was in the book of elementary school.

Soetardjo proposal regarding the red and white flag as the national flag was in accordance with Soempah Pemoeda 1928, which had no realization. Ironic, the foreign nation in Indonesia often displayed their flag beside the Dutch flag.

Until the arrival of the J apanese, the use of the name of Indonesia was still forbade by the Dutch colonial governemnt, particularly in the official letters. M. Thamrin, a political figure and Volksraad expert from Betawi, in October 1939 had propose a notice to the Volksraad (the Dutch East Indies Parliament) to officially using the name of Indonesia for referring to the state or nation. Thamrin's notice was a hot issue in the Volksraad council at that era. Until that era the official name was Nederlandsche-Indie, while the people were called the inlander by the Dutch. There were only the native press who were often wrote Indonesia to refer to the nation and the country since the second decade of the 20th century. For the educated community and the Indonesia movement community, the name of inlander had a negative connotation, because in the Dutch's law it was at the lowest level. Their right was different from the European and the other foreign 
people. The reason why the name of Indonesia was forbid in the official letter because it was considered might cause confusion for the other countries, in other word, it mau ruin the form of the Nederlandsch-Indie. The use of Indonesia name was considered as a political statement as desired by the political parties. This purpose may lead to a political confession, both "the country of Indonesia" or "the nation of Indonesia". The Dutch were always critize the use of Indonesia in everything. Therefore the Dutch mass media (in Sumatra) until 1939 was never use the word Indonesia. For the Indonesia movement community, particularly the mass media, they had already use the word Indonesia. Since the establishment of Volksraad in 1918. Many organization, community, and political party also use the Indonesia in their name such as Partai Nasional Indonesia (PNI), Partai Syarikat Islam Indonesia (PSII), Partai Indonesia Raya (Parindra), Gerakan Indonesia (Gerindo), etc. The use of the name of Indonesia was debated once more in 1941, when a journalist of Tjaja Timoer and the figure of Indonesia Movement, Sjamsoedin Soetan Makmoer made a speech in PPRK radio. J akarta - Sjamsoedin speech text to read in the radio was checked and the Indonesia word in that text was write off by Hoofdparket and replaced with the worj Hindia Belanda (Penjedar, no 2, $9 \mathrm{~J}$ anuary 1941).

Pewarta Deli was published in 1920, had the motto of "organ untuk segala bangsa". At least this newspaper had the impression that they were for every nation in Nederlancshe-Indie. From the research that study the newspaper since the end of the second decade of the $20^{\text {th }}$ century, the use of the word Indonesia is rare in the newspaper published in the North Sumatra. The journalists were often using the word Hidnia Belanda, Hindia Neerland as the reference for Indonesia. The natives in that area they called "boemi poetra", this word was more popular in the newspaper before Soempah Pemoeda 28 October 1928. In another side, the Eueropean prefered to called the native as inlander or indier. Both names was disrespected by the natives because those names indicated Indonesian as stupid and suppressed. Boemi poetra had identified their identity as equal as the other nation such as Aceh, Batak, J avanese, Sundanese, Betawi, Minangkabau, Minahasa, and others. Therefore, in the second decade there were many youth organization based on ethnic. This ethnic organization was a manifestation of a process toward Indonesia.

Another problem was who were these Indonesian. This was an interesting topic in the press before war. The main problem was the Indo community in the state of Indonesia. The Indos in the colonial law was included into the European law. However, most Indos wanted to be the citizen of Indonesia, because they were born in Indonesia, in they have Indonesian blood. These Indoes had formed Insulinde party, which at theend would joint Parindra. However, Parindra would not accept Insulinde. In Gerindo congress on 1939 in Palembang, Gerindo could understand the Insulinde purpose. In the vision of Gerindo, nationalism not supposed to be limited only to the skin color and origin. According to Gerindo, nationalism was the same destiny, goal, and wish, which is to pursuit Indonesia. Therefore the half-blooded community that had the same idea and destiny means that they are Indonesia (Penjedar No. 33, 13 Ogos 1939). 
HISTORIA:

International J ournal of History Education, Vol. XII, No. 1(J une 2011)

\section{Mass Media and Nationality Movement}

After the communist insurgency in 1926 in Silungkang, West Sumatra, every political activity was strictly watched. However, the dutch colonial pressure was not lowering the anti-colonial spirit. There were more movements in 1930s. A.M. Pamoentjak, an intellectual and the movement figure of Sumatra explained that the political movement was risen up again.

Every party was allowed to express the political ideas. The issues risen up in those movements was Islam and "cinta tanah air dan bangsa (patriotism)". This enthusiasm was higher because the education was also better. Muhammad Yamin in the Volksraad meeting on 12 J uly 1939 explained that the political purpose of Indonesia was the Indonesia indepence. The Purpose must be obtained through a representative institution, this institution must work immediately, in accordance to the society wished. The meaning of this purpose was to be detached from the capitalist economy, had our own power, and arrange in our own socialcultural life. Yamin decided to cooperate with the Dutch to obtain Indonesia idependence, rather that achieving it with our own power. In addition, Yamin was not only refused Indonesia as the part of Dutch, but also refuse that Indonesian should have their parliament. Yamin was also refuse any kind of changing that will cause loss to the society and accept every establishment and change that might get Indonesia closer to its independence (Pandji Islam, 31 uli 1939). Kongres Indonesia was held in 1939 and stated their purposes which include: to obtain the Indonesia with parliement and Gabungan Politik Indonesia as the executif body. Accordingly, on 13-14 September 1941 Kongres Rakyat Indonesia was reheld and discuss about the legalizing of the Kongres Rakyat Indonesia principles, deciding the next congress, and developing the Majelis Rakyat Indonesia. Majelis Rakyat Indonesia was the organization of all views of all Indonesian movements. Majelis Rakyat Indonesia effort was to attempt independent education in doing the parliement works. In other word, they prepared the parliement while waiting the real Indonesian parliament to be established (Penjedar No 38, 18 September 1941).

After the communist insurgency in 1926, 1930s was the years for the people movements. Many political parties appeared. Two political partty was born before 1940s, Gerakan Rakyat Indonesia and Partai Syarikat Islam Indonesia. Thesenew parties cooperated with the government, that's why they were included in the parliament. Parindra was also used this cooperation trick. Another political party PSII and PNI have different point of view, they did not want to cooperate with the government to reach the goal of Indonesia. Because there are two opposite big wave in the movement tactics, the competition among parties was also higher. The competition between parties who liked to cooperate with the governemnt was getting higher, they compete to had a position in the parliament and government isntitution. The strengthen people movement was also the result the chance of the international conflict between the East and the West, between the J apanese and Uni Soviet, this conflict was considered to have affected Indonesia politic condition. The Dutch Kingdom had also suffered crisis because the high cost or 
war. Meanwhile, although there were announcement from the Dutch kingdom to be prepared for any possibilities of conflict and war, but Indonesian did not care a little. Newspaper and magazine did not considere that the Dutch worry was Indonesian problem. Thisattitudewas related to thecondition that theIndonesian has faced various problems. The first was the poverty in the colonialized land. According to the press analisys, this incosideration of Indonesian toward the Dutch kingdom notice to support the war was initiated by the poverty. According to the media analysis, the society has been strugling with poverty, thinking about their suffering life, therefore they would not able to support the financial of the war and help the Dutch in war. Second, Indonesian had never been invited and involved in the military training. Therefore, it would be imposible for them to defend the colonilized land in war.

The issue of Indonesia with parliament was intense in mass media during 1930s. In 1918 Volksraad of Nederlansche-Indie was ready, and the member was appointed by the Dutch Colonial Government. The bigger power of Dutch government in that institution had caused the Indonesian to force them adding more native members.

Volksraad was and important institution in Indonesia political movement. However, not all parties and movement figures liked this idea, because some political figures had the opinition to not cooperating with the Dutch Colonial Government. Sincethe beginning, thesemovements figures had been themember of volksraad, but in 1923 they refuse to joint the voldksraad because it was not on the people's side. Therefore, H. A. Salim invited volksraad in a discussion. In 1927 volksraad was rearranged. Eventhough the administrator was still inaugurated by the King, but the member's number was added. The Volksraad was usually 48 membesr, it was increased to 60 members. 38 were elected and 23 was inaugurated. The elected members consisted of 20 natives, 15 Dutch, and 3 foreigners. The inaugurated members were 5 natives, 15 Dutches, and more or less 2 foreigners. The next two yeard, the natives inaugurated was 10 people (Furnivall, 1983: 381-383). This improvement was attracted several movement figure to once again fight in volksraad. Therefore, when approaching the 1930s, more movement activists were trying to become the volkstaad member. After the middle of the second decade this position New political issue would immediately spread by the mass media though out Indonesia.

Mass media as an instrument of the national movement had an important role in spreading the political issues from the volksraad building and discussed it in the mass media. Mass media had made the issues of volksraad council closer to the issues in the society. From the mass media the movement figure could interactand understood what was happen in Indonesia, either in the governmental central or in a remote area in East Sumatra. Some important issue of volksraad and publish continuously in mass media was the Sutardjo petition, Indonesia with Parliement, the revocation of $177 \mathrm{~S}$ Law.

Panji Islam (17J une 1940) had the headline of "Menetapkan Pemerintahan Demokrasi di Indonesia (Establishing a Democaratic Government in Indonesia)". In $15 \mathrm{~J}$ une 1940, a volksraad meeting was opened by the Nederlandche-Indie 
Governor General. The Governor said that volksraad was more important at than time as the highest democratic institution in Indoensia, to bear the government burden. The Governor was sure that there would a change that would realized what had been the dream of the people. The Governor General proposed three recommendation clauses. First, to help the kingdoms that had been the friend of Dutch.Kingdom. Second, Defense the Nederlansche Indie. Third, advancing the people life regligiously and physically. But the Governor General did not mention anything about the Indonesia Status when it was occupaied by the J apanese.

The Gorvenor's speech was very important because Dutch was just occupied by German. Therefore, there was no power in Indonesia (staat van beleg). Therefore many countries such as German, United State, France, England, and J apan wanted to occupied Indonesia. All of them stated to guarantee the Indonesi'a sfatey.J apanese was really ambitious, They stated the authorization status in Indonesia to the Dutch when war was still occured in Europe. After the Dutch was defeated by German, J apan was stating the Indonesia's status. After several European country promised to gurantee and respect the Indonesia condition, J apan was also support, but they were always watch. When the United State of America increased their action to help Indonesia, Japan was angry. Moreover when there was a news that J apanese fisherman's boat was shot by the Dutch soldier in Bangka water area. The capitalists competition in Indonesia was getting strict. Panji Islam said that the higher competition in Indonesia may result in more promises from the Dutch to expand volksraad rights. Panji Islam (17J uni 1940) was welcoming those promises as long as it could improve the government institutions.

\section{Developing Culture and Language}

Indonesia nationality spirit could also be seen in the use of Indonesian Language as an identity. The spirit of using Indonesian language had been started since the Sumpah Pemuda (1928), eventhough the use was still limited to the official event, correspondency, and in newspaper. This spirit can also be seen in the first Kongres Bahasa Indonesia in Solo, 25 J une 1938. The congress showed a further nationality of Indonesia which expresses in the tittles presented. The title were "Sejarah Bahasa Indonesia" (Sanoesi Pane), "Bahasa Indonesia dalam Pergoeroean" (Ki hadjar Dewantara), "Bahasa Indonesia dalam badan Perwakilan"(Soekrdjo Wirjopranoto), Edjaan bahasa Indonesia (K St Pamoentjak), "Bahasa Indonesia dalam Persoerat-kabaran”( Adinegoro), "Kesoesastraan Indonesia Baroe (S. Takdir Alisjahbana), "Mentjeptkan Penjebaran Bahasa Indonesia" (M Tabrani), "Menjesoeaikan kata dan faham asing kepada bahasa Indonesia"(Mr. Amir Sjarifoedin) and "Bahasa Indonesia sebagai bahasa persatoean dan bahasa keboedajaan" (Mr. Mohd. Yamin). From those papers it can be seen that the experts involved in this congress came from various filed; language, civilization, literature, and journalist. The congres' participants presented the potential and chalange of Bahasa Indonesia 
in the future. Therefore they proposed to develop an institution for the national language, in order to develop thelanguage and maintain its existence, and to avoid it from the influence of foreign language that may ruin the Bahasa Indonesia. The different languages in every region should no be gone in the future. They thought about how to protect those vernaculars, which had become our character (Pedoman Masjarakat No.25, 22 J une 1938). the press opinion in that era stated that language was considered as the center of improvement of all field.

The language use by the native press in the Indonesia national movement era was the daily language of Malayan. The language had been used in daily social life and inter island trading since centuries in Indonesia. According to Sanusi Pane in the Kongress Taman Siswa 1941, there were three category of Malay language. First the Malayan used in daily life by the natives. Every region had their own version of Malayan. Both, Malayan Pasar was use in the inter nation relationship, which was also different. Third Malayan may not be separated by effect from outside factor, such as the langguage of Sanskrit, Arab, Dutch, English, and another foreign language, including the J avanese. Futhermore, this perspective explain that the Indonesian Language is not Riau Malayan Language. However, it can be seperated by any other language that had influenced the Malayan language. Futher more this opinion explain that Indonesian language is not the Malayn Riau. Riau influence might not be so great, because Melayu is not only Riau. Riau Malayan was only a step. Therefore, the Malayan used as the language of Indonesian not only refers to one ethnic group (Penjedar, 6 November 1941).

The improvement in education and the native welfare was the serious attention of the Dutch colonial in the 20th century. The effect was the publishing development in the native community. Therefore the Dutch Colonial Governement thought that it was necessary to control the native development. Accordingly, the Dutch Colonial had also influence the development of Malayan become Indonesian' language. The Dutch develop the political policelanguage to control the Malayn language. Because many languages were continue to be used, such as Sundanese,J avanese, Bugis, etc. TheColonial government considered this language diversity as not effective in controlling the native's politic. Therefore, Instituut voor inlands en de Volkslekteur (people's reading park) was established in 1908, which was latered into Balai Pustakan in 1917. This institution was to control and distribute reading materials for the natives. Many natives writes was directed to publish their writings in Balai Pustaka. Of course the publicity must be in accordance with the Dutch desires. The published book should not contain politic and should not rise up thenationality spirit. Balai Pustaka as the publishing that was allowed by the Dutch Colonial was also translated some West works such as the work of J ames Oliver Curwood, Hector Malot, Leo Tolstoy, C. Dickens, dan Mark Twain. These work was distributed to the entire nation and schools (Kroef, 1954). The published work had no political contain, but the resistence of custom. This policy was of course necessasy to made unstable the natives culture and inserting the European culture to the mind of Indonesian people. 
National movement also have a big influence in the language development. Various social and political ornganization presented since the first decade of the $20^{\text {th }}$ century was using the Indonesian language as a men to communicate. Budi Utomo(1908), Syarikat Islam (1912), Muhammadya (1912), NU (1926), etc. were some of them. The development was firmer since the proclaim of Sumpah Pemuda on 28 October 1928, which one point said "berbahasa satu, bahasa Indonesia (one language, Indonesian language)". That sentence was strengthen the development of Malayn to become the Indonesian Language. Since then the words or Indonesia and Bahasa Indonesis as the identity was used more often.

The press was very important in developing the language of Indonesia, because it spread any news which indirectly had become the unifier. Press often privide the spirit to improve to the society. The continous use of Malayan in various reading material and publishing had made the soictey getting more familiar with the language.

The Malayan use in press was not the standard language, it was very dynamic and flexible. The press was not only using the Malayan, they often mixed it with the Dutch, Arabic, and several ethnic language. This could enrich the laguage to form the Language of Indonesia, which getting more further from the source Malayan language. 


\section{REFERENCES}

Andalas, 29 J anuary 1924

Busyairi, B. (1985). Catatan Perdjuangan H.M. Yunan Nasution. J akarta: Penerbit PT. Pustaka Pandji Mas

Departemen Pendidikan dan Kebudayaan. (1977). Sejarah Kebangkitan Nasional Daerah Sumatera Utara.

Elson, R.E. (2009). The Idea of Indonesia Sejarah Pemikiran dan Gagasan. J akarta: Serambi.

Furnivall, J.S. (1983). Hindia Belanda Suatu Pengkajian(terj).Dewan Bahasa dan Pustaka Kementerian Pelajar Malaysia, Kualalumpur:

Harahap, B.A. (1996). “Willem Iskander: Guru yang Terlempar jauh ke Masa Depannya," in Kkadjat hartojo et.al.(ed.). Nalar dan naluri 70 tahun Daoed J oesoef. J akarta: CSIS.

Indish Verslag, 1930.

Indisch Verslag, 1934

Lubis, M.A. "Pantja Zaman Persuratkabaran di Sumatra Utara”, in SPS, 1958, Kenangan Sekilas sedjarah Perdjuangan Pers Sebangsa. J akarta: SPS.

Muhammad 'TWH. Sejarah Pers di Sumatra Utara, Yayasan Pelestarian Fakta Perjuangan Kemerdekaan Republik Indonesia

Kroef, J .M. 'Modern Trend in Indonesiaan Literature', J ournal of East Asiatic Studies, Vol. III, No. 2, J anuari, 1954.

Pandji Islam, 31J uli 1939

Pedoman Masjarakat No.25, 22 J une 1938

Pelly, U. (1998). Urbanisasi dan Adaptasi Peranan Misi Budaya Minangkabau dan Mandailing. J akarta: LP3ES.

Pelita Andalas, 23 September 1924

Penjedar, no 2, 9 J anuary 1941

Penjedar No 38, 18 September 1941)

Penjedar, 6 November 1941

Pewarta Deli, 3 March 1936

Pewarta Deli, 27 December 1937

Panitia Almanak nasional Sumatra \& Komando Antar Daerah. (1969). Almanak Sumatra. Medan: Panitia Almanak Nasional Sumatra \& Komando Antar Daerah Sumatra. 
Prakoso, M.A. (ed). 1984. "Sejarah Singkat Surat Kabar di Indonesia” in Katalog Surat Kabar. J akarta: Pernas. Khas bahagian Pengantar.

Reid, A. (1979). The Blood of the people and the End of Traditional Rule in Nothern Sumatra. Kualalumpur: Oxford University Press

Rosjidi, A. (1990). M, Natsir Sebuah Biografi, J akarta: Girimukti Perkasa.

Suryadinata, L. (1976). Peranakan Chinese Politic in J ava. Institute of Southeast Asian Studies.

Said, M. (1976). Pertumbuhan dan Perkembangan Pers di Sumatera Utara. Medan: Waspada.

Said, M. (1976). Soetan Koemala Boelan (Flora): Raja Pemimpin Rakyat, Wartawan, Penentang Kezaliman Belanda Masa 1912-1932. Jakarta: UI Press,

Siburian, S.P. (2009). “Media Komunikasi Pilar Pekabaran Injil Kajian atas Peran Majalah Immanuel HKBP,

1890-1940". J urnal Sociae Polites: J urnal Ilmiah Ilmu Sosial dan Ilmu Politik Vol. 10, No.28, Fakultas Ilmu Sosial dan Ilmu Politik Universitas Kristen J akarta.

Soekarno, (1970). Nationalism, Islam and Marxism (translated by Karel H Warouw and Peter D Weldon). New

York: Cornell University.

Williams, L. (1960). Overseas Chinese nationalism: the genesis pan-Chinnese movement in Indonesia 1900-1916. Massachusetts: The Massachusetts Institute of Technology. 
WANNOFRI SAMRI

Medan Press: National Identity Finding Process 